\title{
PENGARUH GAYA KEPEMIMPINAN TERHADAP KINERJA MASYARAKAT PADA BUMDES DESA ROMBASAN SUMENEP
}

\author{
Mohammad Amir Furqon \\ Moh. Amin Qudbi \\ UNIVERSITAS MADURA
}

\begin{abstract}
Abstrak
Hasil perhitungan dengan menggunakan uji $\mathrm{F}$ di peroleh $\mathrm{F}$ hitung sebesar 25,573 dan apabila dikonsultasikan dengan $\mathrm{F}$ tabel sebesar 2,63 menunjukkan $\mathrm{F}$ hitung > F tabel. Maka hipotesa penulis bahwa diduga variabel Gaya Kepemimpinan Klasik $\left(X_{1}\right)$, Gaya Kepemimpinan Otokrasi $\left(X_{2}\right)$, dan Gaya Kepemimpinan Demokrasi $\left(X_{3}\right)$ berpengaruh secara simultan terhdap variabel terikat yaitu Kinerja Masyarakat (Y) Pada BUMDES Desa Rombasan Sumenep dapat dibuktikan kebenarannya.

Berdasarkan hasil perhitungan diperoleh $\mathrm{t}$ hitung untuk variabel Gaya Kepemimpinan Klasik $\left(X_{1}\right)$ sebesar 3,547 dan jika dikonsultasikan dengan $t$ tabel sebesar 1,685 didapat $t$ hitung $>t$ tabel maka dapat diambil kesimpulan bahwa variabel Gaya Kepemimpinan Klasik $\left(X_{1}\right)$ berpengaruh secara parsial terhadap Kinerja Masyarakat $(Y)$ pada BUMDES dapat dibuktikan. Untuk variabel Gaya Kepemimpinan Otokrasi $\left(\mathrm{X}_{2}\right)$ sebesar 4,067 dan jika dikonsultasikan dengan $\mathrm{t}$ tabel sebesar 1,685 didapat $\mathrm{t}$ hitung $>\mathrm{t}$ tabel maka dapat diambil kesimpulan bahwa variabel Gaya Kepemimpinan Otokrasi $\left(\mathrm{X}_{2}\right)$ berpengaruh secara parsial terhadap Kinerja Masyarakat $(\mathrm{Y})$ pada BUMDES dapat dibuktikan. Untuk variabel Gaya Kepemimpinan Demokrasi $\left(X_{3}\right)$ sebesar 5,256 dan jika dikonsultasikan dengan $t$ tabel sebesar 1,685 didapat $t$ hitung $>t$ tabel maka dapat diambil kesimpulan bahwa variabel Gaya Kepemimpinan demokrasi $\left(X_{1}\right)$ berpengaruh secara parsial terhadap Kinerja Masyarakat $(Y)$ pada BUMDES dapat dibuktikan. Dari hasil perhitungan dengan menggunakan uji $t$ ternyata dari ketiga variabel tersebut variabel Gaya Kepemimpinan demokrasi $\left(X_{3}\right)$ nilai t nya paling besar yaitu sebesar 5,256.

$Y=4,471+0,106 X_{1}+0,227 X_{2}+0,715 X_{3}$, nilai konstanta 4,471 yang berarti bahwa apabila $X_{1}, X_{2}, X_{3}$ sama dengan nol maka Kinerja Masyarakat $(Y)$ sebesar 4,471. Koefisien variabel Gaya Kepemimpinan Klasik $\left(X_{1}\right)$ sebesar 0,106 hal ini berarti bahwa bilamana variabel Gaya Kepemimpinan Klasik $\left(X_{1}\right)$ dinaikkan satu - satuan maka akan menaikkan Kinerja Masyarakat (Y) sebesar 0,106. Koefisien variabel Gaya Kepemimpinan Otokrasi $\left(X_{2}\right)$ sebesar 0,227 hal ini berarti bahwa bilamana variabel Gaya Kepemimpinan Otokrasi $\left(X_{2}\right)$ dinaikkan satu satuan maka akan menaikkan Kinerja Masyarakat (Y) sebesar 0,227. Sedangkan
\end{abstract}


koefisien variabel Gaya Kepemimpinan Demokrasi $\left(\mathrm{X}_{3}\right)$ sebesar 0,715 hal ini berarti bahwa bilamana variabel Gaya Kepemimpinan Demokrasi $\left(X_{3}\right)$ dinaikkan satu - satuan maka akan menaikkan Kinerja Masyarakat $(Y)$ sebesar 0,715.

\section{Key Word : Gaya Kepemimpinan, Kinerja Masyarakat. Bumdes}

\section{PENDAHULUAN}

\subsection{Latar Belakang}

Suatu organisasi didirikan karenan mempunyai tujuan yang ingin dan harus dicapai.Organisasi suatu pemerintahan didirikan dengan tujuan untuk meningkatan kesejahteraan masyarakat bangsa secara optimal dan peningkatan ekonomi kepada setiap daerah melaui pengembangan sumber daya alam yang dimiliki.Organisasi pemerintahan didirikan untuk meningkatkan taraf hidup suatu bangsa yang seringkali diukur dengan tinggi rendahnya pendapatan riil perkapita.Tujuan pembangunan ekonomi di samping untuk menaikkan pendapatan nasional riil juga untuk meningkatkan produktifitas masyarakat bangsa pada khususnya.

Namun, semua tindakan yang di ambil dalam setiap kegiatan diprakarsai dan ditentukan oleh manusia yang menjadi anggota organisasi.Organisasi membutuhkan adanya faktor sumber daya manusia yang potensial baik Pemimpin maupun bawahan pada pola tugas dan pengawasan yang merupakan penentu tercapainya tujuan organisasi. Dan salah satu pendekatan dalam meningkatkan produktifitas masyarakat tersebut dapat dilakukan melalui praktek kepemimpinan yang handal,cerdas dan terarah.

Menurut Toha (2001:9) “ kepemimpinan adalah kegiatan untuk mempengaruhi orang lain, atau seni mempengaruhi prilaku manusia baik perorangan maupun kelompok".

Sedangkan menurut handoko (2000:97) menyatakan "bahwa kepemimpinan adalah kegiatan mempengaruhi orang lain atau seni mempengaruhi prilaku manusia baik perorangan maupun kelompok.

Berdasarkan pendapat para ahli di atas maka kepemimpinan pada dasarnya meliputi penggunaan pengaruh seseorang kepada orang lain yang di dalamnya terdapat proses komunikasi,motivasi dan pengawasan dengan tujuan yang ingin di capai. Sehingga dapat di katakan bahwa kepemimpinan yang efektif adalah kepemimpinan yang berhubungan dengan tujuan-tujuan individu, dan kelompok organisasi.

BUMdes (Badan Usaha Milik Desa)
didirikan dengan tujuan dapa
mengurangi tingkat kemiskinan di setiap daerah dan dapat menumbuh kembangkan kemakmuran masyarakat bangsa secara menyeluruh.BUMdes merupakan instrument pendayagunaan ekonomi lokal dengan berbagai macam jenis potensi terutama bertujuan untuk meningkatkan kesejahteraan ekonomi masyarakat Desa Rombasan pada khusunya.Melalui pengembangan usaha ekonomi mereka, BUMdes juga bertujuan untuk memajukan perekonomian desa, meningkatkan kesejahteraan masyarakat desa, memberikan Kepemimpinan terhadap kebutuhan masyarakat dan meningkatkan pengelolaan asset-asset desa yang ada.Pada prinsipnya BUMdes dimaksudkan untuk memperkuat peningkatan kesempatan berusaha, mengurangi pengangguran, sekaligus menjadi penggerak perekonomian di desa.Keberadaan BUMdes juga di tujukan untuk mendorong, memfasilitasi, melindungi dan memberdayakan 
kegiatan perekonomian di pedesaan yang di dasarkan pada potensi desa yang berkembang menurut Budaya Masyarakat setempat.

Untuk mencapai Visi dan Misi tersebut tentunya diperlukan SDM yang berkualitas agar suatu organisasi dapat mewujudkan cita - cita dan harapan masyarakat desa rombasan pada khususnya. Di sini di tuntut peran pemimpin yang mampu menciptakan ide - ide yang inovatif serta berkomitmen guna menumbuhkan semangat kerja sehingga dapat meningkatkan produktifitas serta dapat menciptakan kualitas ekonomi yang baik sesuai dengan apa yang diharapkan.

Selain untuk memperkuat pendapatan desa, BUMdes juga dapat memajukan perekonomian desa serta bertujuan merubah prilaku masyarakat supaya lebih produktif, atau pada akhirnya untuk peningkatan kesejahteraan sosial ekonomi masyarakat desa, serta mendukung optimalisasi program penanggulangan kemiskinan khususnya di Desa Rombasan Sumenep.pemerintah Kabupaten Sumenep terus mendorong agar di desa-desa yang potensi Sumber Daya Alamnya yang sangat mempuni bisa di kembangkan secara bertahap dan terus dilakukan inisiasi. Pendirian Badan Usaha Milik Desa (BUMdes) dimana merupakan suatu kesatuan dari lembaga perekonomian yang ada di desa yang terus di pelihara oleh masyarakat setempat menurut kearifan local.

Desa melakukan proses inventarisir terhadap potensi kekayaan desa dan Sumber daya Manusianya. Hal ini untuk menentukan pilihan dan jenis bidang usaha yang mau di tangani oleh BUMdes karena di tengah masyarakat sendiri telah muncul beragam kegiatan ekonomi seperti simpan pinjam pertokoan meracang, usaha dagang, pertanian, peternakan, dan pertambangan.Demikian juga pendirian
Badan usaha ini membuka usaha yang mendorong masyarakat supaya lebih produktif.Hal ini mengingat bahwa badan Usaha Milik Desamempunyai tanggung jawab sosial untuk membentuk masyarakat produsen. Di tempuh dengan mendorong masyarakat untuk lebih mencintai produk lokal konsumsi masyarakat untuk produk lokal akan mendorong produsen lokal maju dan berkembang. Ketika industri maju ia akan semakin banyak menyerap tenaga kerja lokal tentunya yang ujungnya adalah kesejahteraan masyarakat. Dengan semakin banyak orang yang dihidupinya maka akan semakin makmur suatu masyarakat dan ekonomi desa maju dan mandiri serta sejahtera.

Upaya untuk menanggulanginya harus menggunakan pendekatan multi disiplin yang berdimensi pemberdayaan.Pemberdayaan yang tepat harus memadukan aspek aspek penyadaran, peningkatan kapasitas dan pendayagunaan Sumber Daya Manusiasecara maksimal.Penanggulangan kemiskinan yang bertujuan untuk melakukan pemenuhan hak dasar, pengurangan beban hidup, dan perbaikan kualitas hidup masyarakat miskin pada khususnya. Upaya lain yang dilakukan oleh BUMdes adalah pemberdayaan masyarakat yang bertujuan untuk memperkuat kapasitas kelompok masyarakat konsumtif untuk terlibat dalam pembangunan yang di dasarkan pada prinsip prinsip pemberdayaan masyarakat. Pemberdayaan adalah faktor penting untuk mempengaruhi masyarakat konsumtif supaya lebih produktif dalam upaya untuk mempengaruhi masyarakat tidaklah mudah keputusan masyarakat merupakan suatu proses masyarakat memutuskan untuk memilih jenis usaha dari berbagai usaha yang ada atau dapat di artikan juga sebagai suatu proses masyarakat menentukan pilihan terhadap suatu usaha atau bisnis. 
Oleh karena itu, berdasarkan latar belakang permasalahan diatas maka penulis tertarik untuk mengambil judul penelitian " Pengaruh Kepemimpinan Dan SDM (Sumber Daya Manusia) terhadap Produktifitas Masyarakat dalam mengembangkan BUMdes di Desa Rombasan Sumenep

\subsection{Rumusan Masalah}

Berdasarkan latar belakang masalah maka penulis mengemukakan rumusan masalah pada penelitian ini adalah sebagai berikut:

1. Apakah KEPEMIMPINAN dan SDM secara bersama-sama berpengaruh terhadap Produktifitas Masyarakat dalam mengembangkan BUMdes di Desa Rombasan Sumenep?

2. Variabel apakah yang paling dominan berpengaruh terhadap Produktifitas Masyarakat di Desa Rombasan Sumenep?

\subsection{Batasan Masalah}

Tujuan dari batasan masalah adalah agar masalah yang dirumuskan memiliki batasan yang kuat dan tidak lagi mengalami suatu kekaburan dalam memecahkan masalah. Maka batasan masalah penelitian ini adalah

1.Yang menjadi Responden adalah Masyarakat Asli desa Rombasan yang sedang mengembangkan usahanya yang di bentuk oleh BUMdes Rombasan Sumenep

2. yang di bahas dalam penelitian ini terdiri dari kepemimpinan dan SDM (Sumber daya manusia).

\subsection{Tujuan Penelitian}

Berdasarkan latar belakang masalah dan rumusan masalah maka tujuan penelitian ini adalah:

1. Untuk mengetahui pengaruh Kepemimpinan dan SDM terhadap
Produktifitas Masyarakat di Desa Rombasan Sumenep

2. Untuk mengetahui faktor apakah yang paling dominan berpengaruh terhadap produktifitas masyarakat di desa rombasan sumenep yang meliputi Kepemimpinan Dan SDM (Sumber Daya Manusia)?

\subsection{Manfaat Penelitian}

Manfaat yang bisa di ambil dari adanya penelitian ini adalah sebagai berikut:

1. Bagi Badan Usaha Milik Desa (BUMdes)

Sebagai bahan informasi dan masukan kepada pemimpin/ketua BUMdes untuk di jadikan bahan pertimbangan dalam memenuhi kebutuhan dan harapan masyarakat.

2. Bagi Peneliti

Untuk menerapkan ilmu pengetahuan yang di peroleh dari Universitas Madura dan menambah pengetahuan tentang berbagai macam masalah yang terjadi dalam suatu organisasi terutama yang berhubungan dengan pengaruh Kepemimpinan dan SDM terhadap produktifitas Masyarakat dalam mengembangkan BUMdes dan sebagai pembelajaran bagi penulis sebagai tugas akhir.

3. Bagi Fakultas Ekonomi

Memberikan kontribusi akademis kepada berbagai pihak yang berminat dalam melakukan penelitian di lingkungan Fakultas Ekonomi dan Universitas Madura pada umumnya untuk dapat di jadikan refrensi dan menambah perbendaharaan perpustakaan.

4. Bagi Masyarakat

Untuk menjadi acuan dan sebagai sumber informasi bagi masyarakat sehingga dapat di jadikan pertimbangan dalam pengambilan keputusan untuk mengembangkan usahanya khususnya di Desa Rombasan Sumenep. 


\subsection{Kerangka Pemikiran}

Gambar 1.1

Kerangka Pemikiran Penelitian

Pengaruh Kepemimpinan dan SDM Terhadap Produktifitas Masyarakat dalam mengembangkan BUMdes di Desa Rombasan Sumenep

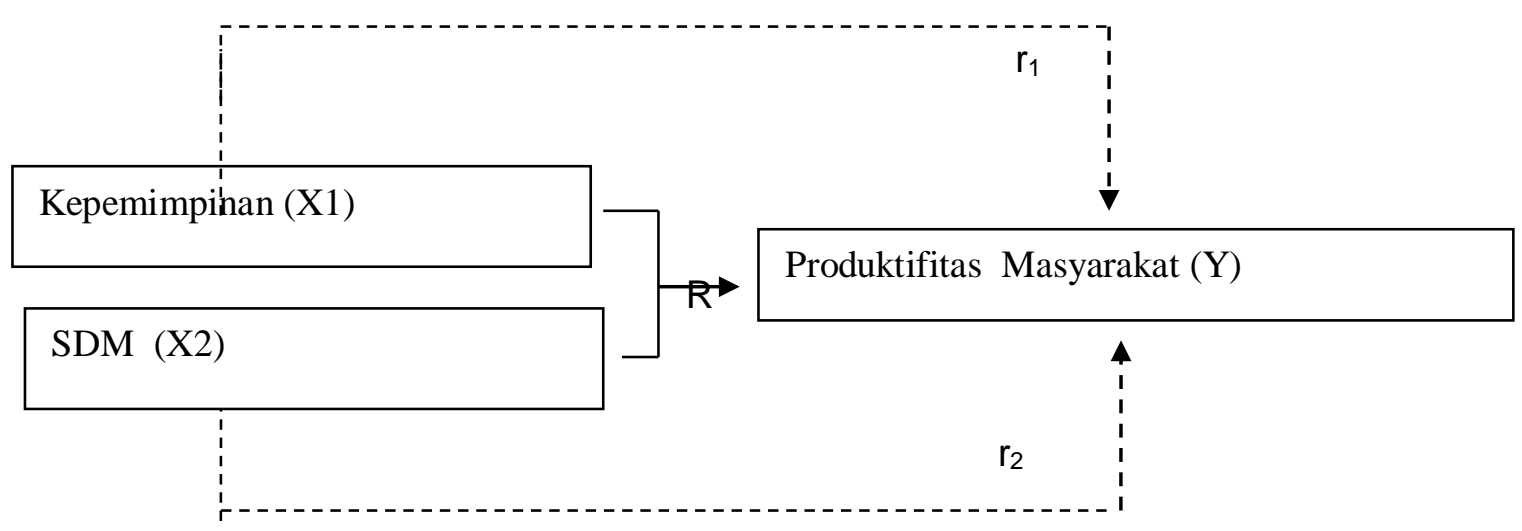

Sumber: BUMdes ( Badan Usaha Milik Desa) Desa Rombasan Kec. Pragaan kabupaten Sumenep

$R(\longrightarrow)$ = hubungan secara simultan ( secara langsung)

r ( - - - - ) = hubungan secara parsial ( secara tidak langsung)

$r$ adalah koefisien korelasi parsial pada factor kepemimpinan dan SDM terhadap produktifitas masyarakat yang terdiri dari:

Variable Bebas (X1): terdiri dari Kepemimpinan dan SDM KepemimpinanMenurut M.C Barnes (2001:155) di mana Variabel ini dibagi menjadi 3 indikator yaitu Komitmen, Inovatif, pengawasan, Dalam meningkatkan produktifitas masyarakat.Sedangkan Variabel SDM di bagi menjadi 3 indikator yakni Kualitas intelektual, Kualitas Spiritual, Kualitas Fisik Dan kesehatan.

Variable Terikat $(\mathrm{Y})$ : yaitu Produktifitas Masyarakat menurut balai pengembangan produktifitas daerah (dalam umar, 2001:11) yang mana variable ini terdiri dari 6 Idikator Yaitu: Kreatif, Objektif, Loyalitas, Solidaritas, Optimisme, dan Tanggung Jawab.

LANDASAN TEORI DAN HIPOTESA

\subsection{Landasan Teori}

2.1.1 Pengertian Kepemimpinan
Kepemimpinan merupakan hal yang sangat penting dalam manajerial, karena dengan kepemimpinan proses manajemen akan berjalan dengan baik dan para masyarakat akan bergairah dalam melakukan tugasnya. Devinisi 
kepemimpinan secara luas meliputi proses mempengaruhi dalam menentukan tujuan organisasi memotivasi prilaku bawahan dalam memotivasi prilaku bawahan untuk mencapai tujuan, mempengaruhi dan memperbaiki kelompok, dan budaya. Selain itu juga mempengaruhi interprestasi mengenai peristiwa peristiwa bawahannya, mencapai sasaran, memelihara hubungan kerja sama dan kerja kelompok dan kerja sama orang orang di luar kelompok.

Menurut Robbins dan judge ( 2008: 315) menyatakan bahwa" kepemimpinan adalah kemampuan untuk mempengaruhi kelompok menuju pencapaian sasaran".

Menurut handoko ( 2009 : 97) bahwa" kepemimpinan adalah kegiatan mempengaruhi prilaku orang lain atau seni mempengaruhi prilaku manusia baik perorangan maupun kelompok".

Berdasarkan pendapat para ahli di atas maka kepemimpinan pada dasarnya meliputi penggunaan pengaruh seseorang kepada orang lain yang di dalamnya terdapat proses komunikasi dari tujuan yang ingin di capai. Sehingga dapat di katakana bahwa kepemimpinan yang efektif adalah kepemimpinan yang berhubungan dengan tujuan-tujuan individu, kelompok organisasi.Literature literature tentang kepemimpinan senantiasa memberikan penjelasan bagaimana menjadi pemimpin yang baik.Suatu organisasi akanberhasil atau gagal sebagian besar ditentukan oleh kepemimpinan.Karenanya pemimpinlah yang bertanggung jawab atas kegagalan pelaksanaan suatu pekerjaan. Hal ini menunjukkan suatu kesimpulan yang mendudukkan posisi pemimpin dalam suatu organisasi pada posisi yang terpenting demikian juga seorang pemimpin di manapun letaknya akan selalu mempunyai beban untuk mempertanggungjawabkan

kepemimpinannya.

Kepemimpinan merupakan faktor penting dalam memberikan pengarahan kepada masyarakat apalagi pada saat-saat masa sekarang ini di mana semua serba terbuka, maka kepemimpinan yang di butuhkan adalah pemimpin yang bisa memberdayakan dan memotifasi para masyarakat kepemimpinan yang bisa menumbuhkan motivasi kerja masyarakat adalah kepemimpinan yang bisa menumbuhkan rasa percaya diri para masyarakat dalam mengembangkan usahanya masingmasing.

\subsubsection{Jenis - jenis kepemimpinan}

Adapun Gaya Kepemimpinan tersebut adalah sebagai berikut:

1. Gaya Kepemimpinan Otoriter

Gaya kepemimpinan ini menghimpun sejumlah prilaku atau gaya kepemimpinan yang bersifat terpusat kepada pemimpin satu - satunya penentu, dan penguasa, pengendali organisasinya dan kegiatannya dalam usaha mencapai organisasinya.

2. Gaya Kepemimpinan Demokratis

Gaya kepemimpina menempatkan manusia sebagai faktor pendukung terpenting dalam kepemimpinan yang di lakukan mengutamakan orientasi pada hubungan dengan anggota organisasi.

3. Gaya Kepemimpinan Bebas

Gaya kepemimpinan ini pada dasarnya berpandangan bahwa anggota organisasi mampu mandiri dalam membuat keputusan atau mampu mengurus dirinya masing masing dengan sedikit mungkin pengarahan atau pemberian petunjuk dalam merealisasikan tugas pokok masing - masing sebagai bagian dari tugas pokok organisasi.

\subsubsection{Sumber Daya Manusia}

Manusia merupakan sumber daya paling penting dalam usaha suatu organisasi, untuk mencapai keberhasilan pengelola organisasi sangat ditentukan oleh kegiatan pendayagunaan sumber 
ISSN 1412-2936

daya manusianya. Berikut ini adalah beberapa definisi sumber daya manusia menurut para ahli yaitu: Menurut Flippo (2007:11) mengemukakan "bahwa manajemen personalia adalah perencanaan, pengorganisasian, pengarahan, dan pengendalian dari pengadaan, pengembangan, kompensasi, pengintegrasian, pemeliharaan, dan pemberhentian karyawan, dengan maksud terwujudnya tujuan suatu perusahaan, individu, karyawan dan masyarakat. Sedangkan menurut Mangkunegara (2007:2) menyatakan "bahwa sumber daya manusia adalah suatu pengelolaan dari sumber daya yang ada pada individu (pegawai).

Manajemen sumber daya manusia secara garis besar sama yaitu bahwa, manajemen sumber daya manusia adalah mengatur semua tenaga kerja secara efektif dan efisien dengan mengembangkan kemampuan yang mereka miliki dalam mewujudkan tujuan perusahaan, karyawan dan masyarakat. Dengan memiliki tujuan tertentu maka tenaga kerja akan termotivasi untuk bekerja sebaik mungkin.

\subsection{4 fungsi fungsi Sumber Daya Manusia}

Fungsi sumber daya manusia sangat luas, hal ini disebabkan karena tugas dan tanggung jawab manajemen sumber daya manusia untuk mengelola unsur-unsur manusia se efektif mungkin agar memiliki suatu tenaga kerja yang memuaskan. Menurut Hasibuan (2007:21) Fungsi-Fungsi sumber daya manusia meliputi 3 Faktor yaitu:

1. Kualitas Intelektual

a. Perencanaan

Perencanaan ( human resources planning) adalah merencanakan tenaga kerja secara efektif dan efisien agar sesuai dengan kebutuhan perusahaan dalam membantu terwujudnya tujuan. Perencanaan dilakukan dengan menetapkan

kepegawaian

program

meliputi

pengorganisasian, pengarahan,

pengendalian, pengadaan,

pengembangan, kompensasi,

pengintegrasian, pemeliharaan,

kedisiplinan dan pemberhentian karyawan. Program kepegawaian yang baik akan membantu tercapainya tujuan perusahaan, karyawan, dan masyarakat.

b. Pengorganisasian

Pengorganisasian adalah kegiatan untuk mengorganisasi semua karyawan dengan menetapkan pembagian kerja, hubungan kerja, delegasi wewenang, integrase dan koordinasi dalam bagian organisasi (organization chart).Organisasi hanya merupakan alat untuk mencapai tujuan. Dengan organisasi yang baik akan membantu terwujudnya tujuan secara efektif.

c. Pengarahan

Pengarahan (directing) adalah kegiatan mengarahkan semua bawahan/ karyawan, agar mau bekerjasama dan bekerja secara efektif dan efisien dalam membantu tercapainya tujuan perusahaan,organisasi, karyawan, dan masyarakat.Pengarahan dilakukan pemimpin dengan menugaskan agar mengerjakan tugasnya dengan baik.

d. Pengendalian

Pengendalian (controlling) adalah kegiatan mengendalikan semua karyawan, agar mentaati peraturan-peraturan perusahaan dan bekerja sesuai rencana.Apabila terdapat kesalahan atau penyimpangan, diadakan tindakan perbaikan dan penyempurnaan rencana.Pengendalian karyawan meliputi kedisiplinan, perilaku, kerjasama, pelaksanaan pekerjaan, dan menjaga situasi lingkungan pekerjaan. 
2. Kualitas Spiritual (Kejuangan)

a. Pengembangan

Pengembangan (development) adalah proses peningkatan keterampilan teknis, teoritis 112 konseptual, dan moral masyarakat melalui pendidikan dan pelatihan yang di berikan harus sesuai dengan kebutuhan masyarakat masa kini maupun masa depan.

b. Kompensasi

Kompensasi

(compensation)

adalah pemberian balas jasa langsung (indirect) uang atau barang kepada karyawan sebagai imbalan jasa yang diberikan kepada perusahaan.Prinsip kompensasi adalah adil dan layak Adil diartikan sesuai dengan prestasi kerjanya, layak diartikan dapat memenuhi kebutuhan primernya serta berpedoman pada batas upah minimum pemerintah berdasarkan internal dan eksternal konsistensi.

c. Pengintegrasian (integration) adalah kegiatan untuk mempersatukan kepentingan organisasi dan kebutuhan masyarakat, agar tercipta kerja sama yang serasi dan saling menguntungkan. Perusahaan memperoleh laba, karyawan dapat memenuhi kebutuhan dari hasil pekerjaannya. Pengintegrasian merupakan hal yang sangat penting dalam manajemen sumber daya manusia.

3. Kualitas Fisik Dan Kesehatan

d. Pemeliharaan

Pemeliharaan (maintenance) adalah kegiatan untuk memelihara atau meningkatkan kondisi fisik, mental, dan loyalitas, agar mereka tetap mau bekerjasama. Pemeliharaan yang baik akan dilakukan dengan program kesejahteraan yang berdasarkan kebutuhan serta berpedoman kepada internal dan eksternal konsistensi.

\subsubsection{Hubungan Kepemimpinan Dengan SDM (Sumber Daya Manusia)}

Dalam suatu organisasi ataupun perusahaan sumber daya merupakan factor yang sangat penting untuk tercapainya tujuan tersebut. Kepemimpinan merupakan salah satu factor penggerak tercapainya organisasi ataupun perusahaan.

Kepemimpinan sebagai bagian dari kegiatan seorang manajer yang mempengaruhi tingkah laku orang perseorangan dan kelompok kearah hasil yang diharapkan. Pemimpin organisasi menangani sejumlah entitas yang berbeda - beda organisasi sendiri, sejumlah kelompok informal atau formal di dalamnya, bahkan sejumlah lebih besar orang perseorangan. Masing masing entitasnya mempunyai sejumlah kebutuhan yang harus di penuhi atau sasaran yang harus di capai.Pemimpin merupakan kekuatan aspirasional, kekuatan semangat, dan kekuatan moral yang kreatif. Yang mampu mempengaruhi anggota untuk merubah sikap, sehingga mereka menjadi conform dengan keinginan pemimpin. Kemampuan atau kecerdasan mendorong sejumlah orang dua orang atau lebih agar bekerja sama dalam melaksanakan kegiatan - kegiatan yang terarah pada tujuan bersama.

Keberhasilan suatu organisasi baik berbagai keseluruhan maupun berbagai kelompok dalam suatu organisasi tertentu sangat tergantung pada mutu kepemimpinan yang terdapat dalam suatu organisasi tertentu, sangat tergantung pada mutu kepemimpinan yang terdapat dalam organisasi yang bersangkutan.Siagian

(2002:127) berpendapat "bahwa kiranya dapat di katakana mutu kepemimpinan yang terdapat dalam suatu organisasi memainkan peranan yang sangat dominan dalam keberhasilan organisasi tersebut dalam menyelenggarakan 
berbagai kegiatannya terutama terlihat dalam kinerja para pegawainya.

\subsection{6 kepemimpinan yang mengacu terhadap produktifitas masyarakat \\ METODE PENELITIAN}

\subsection{Pengertian Metode Penelitian}

\subsubsection{Lokasi Penelitian}

Adapun lokasi penelitian untuk mengetahui pengaruh factor Kepemimpinan BUMDES terhadap produktifitas masyarakat dalam mengembangkan usahanyadi desa Rombasan Sumenep.Adalah direncanakan hanya di kecamatan Pragaan Kabupaten Sumenep Karena yang menjadi Responden adalah masyarakat asli desa Rombasan Sumenep yang sedang mengembangkan usahanya.

\subsubsection{Jenis Penelitian}

\subsection{Populasi dan Sampel}

\subsubsection{Populasi}

Populasi dalam penelitian ini adalah masyarakat asli Desa Rombasan yang mengembangkan usahanya yang di bentuk oleh BUMDes (Badan Usaha Milik Desa) di Desa Rombasab Sumenep yan berjumlah 40 Responden.

\subsubsection{Sampel}

Sampel yang di ambil oleh peneliti dalam penelitian ini adalah seluruh populasi yaitu 40 orang sehingga penelitian ini merupakan penelitian populasi.

\subsection{Teknik Pengumpulan data}

Adapun tehnik pengumpulan data pada penelitian ini melalui:

a. Survey pendahuluan, berupa penelitian secara umum terhadap masyarakat untuk mengetahui permasalahan yang di hadapi.

b. Penelitian lapangan, sebagai satu upaya dengan melakukan survey terhadap objek yang akan di teliti untuk memperoleh data primer secara langsung melalui:

1. WAWANCARA

Teknik ini dilakukan dengan melakukan Tanya jawab secara langsung kepada respondent. Hal ini dilakukan untuk memperjelas terhadap pertanyaan yang di anggap kurang jelas oleh respondent.Di samping itu tehnik ini untuk mengetahui secara lebih mendetail beberapa alasan respondent memberikan penilaian tertentu terhadap pertanyaan yang di ajukan.

\section{KUESIONER}

Teknik pengumpulan data yang digunakan pada penelitian ini dengan cara menyebarkan kuesioner kepada para respondent. Respondent di minta untuk menanggapai dengan sikapnya terhadap variable yang ada dengan menggunakan skala penelitian model likert dengan rentangan 1 sampai 5 untuk mengidentifikasi jawaban sangat tidak setuju - sangat setuju.

Adapun skala penilaiannya sebagai berikut:

a. NILAI 1 menunjukan jawaban/pendapat sangat tidak setuju

b. NILAl 2 menunjukan jawaban/pendapat tidak setuju

c. NILAl 3 menunjukan jawaban/pendapat cukup setuju

d. NILAl 4 menunjukan jawaban/pendapat setuju

e. NILAl $\mathbf{5}$ menunjukan jawaban/pendapat sangat setuju

C. Studi kepustakaan

Yaitu dengan mencari data dan informasi berdasarkan buku literature dan Koran, majalah, dan lain sebagainya. 


\subsubsection{Pengujian Instrument Data}

\subsection{Uji Validitas}

Uji validitas data bertujuan untuk mengetahui sejauh mana validitas data yang diperoleh dari penyebaran kuesioner. Uji validitas data dengan menggunakan metode korelasi productmoment (pearson correlation)

Data dikatakan valid apabila $r$ hitung lebih besar $(>)$ dari $r$ table. Selain itu juga bisa dilihat dari signifikasinya, jika nilai signifikasinya lebih besar dari 0,05 maka data tersebut dapat dikatakan tidak valid. Jika nilai signifikasinya lebih kecil dari 0,05 maka data tersebut dikatakan valid (yarnest 2003:65) selain itu data dikatakan valid apabila memiliki koefisien korelasi > 300 (sudarmanto 2005:88) dengan demikina semua butir pertanyaan atau pertanyaan tersebut dapat di gunakan dan dapat dipercaya untuk mengumpulkan data yang di perlukan.

\subsubsection{Uji Reliabilitas}

Pengujian keandalan alat ukur dalam penelitian ini menggunakan reliabilitas metode cronbach alpha (denim 2000:199)

Pedoman untuk memberikan interpretasi terhadap koefisien reliabilitas (alpha) adalah sebagai berikut:

Tabel 3.1

Pedoman Untuk Memberikan Interpretasi Terhadap Koefisien Reliabilitas

(ALPHA)

$\begin{array}{lll}\text { NO } & \text { INTERVAL } & \text { KRITERIA } \\ 1<, 200 & \begin{array}{l}\text { Sangat } \\ \text { rendah }\end{array}\end{array}$

$$
\begin{aligned}
& 2 \quad 0,200 \text { - Rendah } \\
& 0,399 \\
& 3 \quad 0,400 \quad-\quad \text { Cukup } \\
& 0,599 \\
& 4 \quad 0,600 \quad-\quad \text { Tinggi } \\
& 0,799 \\
& 5 \quad 0,800 \text { - Sangat } \\
& 1,00 \text { tinggi }
\end{aligned}
$$

Sumber : Yarnest (2003:96)

\subsection{Teknis Analisis dan Uji Hipotesis}

\subsubsection{Teknik analisis}

Pada penelitian ini menggunakan penghitungan dengan program SPSS. Adapun analisisnya, terdiri dari dua analisis yang terdiri dari analisis kualitatif dan analisis yang bersifat kuantatif:

1. Analisis kualitatif adalah untuk memberikan gambaran tentang objek yang akan diteliti dengan menggunakan skala linkert sebagai berikut :

$\begin{array}{ll}\text { Sangat setuju } & =4,51 \mathrm{~s} / \mathrm{d} 5,00 \\ \text { Setuju } & =3,51 \mathrm{~s} / \mathrm{d} 4,50 \\ \text { Cukup setuju } & =2,51 \mathrm{~s} / \mathrm{d} 3,50 \\ \text { Tidak setuju } & =1,51 \mathrm{~s} / \mathrm{d} 2,50 \\ \text { Sangat tidak setuju } & =1,00 \mathrm{~s} / \mathrm{d} 1,50\end{array}$

2. Analisis kuantitatif adalah untuk memberikan gambaran tentang kondisi objek yang diteliti berdasarkan perhitungan statistic yaitu dengan menggunakan persamaan regresi sederhana, menurut pendapat jarwanto dan pengestu (2001:309) sebagai berikut: 


$$
\mathrm{Y}=\mathrm{a}+\mathrm{b}_{1} \mathrm{X}_{1}
$$

Dimana :

$\mathrm{Y}=$ variable terikat yang 115 ditentukan oleh besarnya $\mathrm{X}$

$\mathrm{X}=$ variable bebas yang menentukan besarnya $Y$

$$
\begin{array}{ll}
\mathrm{b} & =\text { koefisien korelasi } \\
\mathrm{a} & =\text { nilai kostanta }
\end{array}
$$

sedangkan untuk memberikan pedoman dari koefisien korelasi maka penulis mengambil pendapat sugiono (2001:149) sebagai berikut :

\section{PEDOMAN UNTUK MEMBEDAKAN INTERPRETASI KOEFISIEN KORELASI}

$\begin{array}{ll}\begin{array}{ll}\text { INTERVAL } \\ \text { KOEFISIEN }\end{array} & \begin{array}{l}\text { TINGKAT } \\ \text { HUBUNGAN }\end{array} \\ 0,00-0,199 & \begin{array}{l}\text { SANGAT } \\ \text { RENDAH }\end{array} \\ 0,20-0,399 & \text { RENDAH } \\ 0,40-0,599 & \text { SEDANG } \\ 0,60-0,799 & \text { KUAT } \\ 0,80-1,00 & \text { SANGAT } \\ & \text { KUAT }\end{array}$

Sumber data : Sugiono (2001:149)

Untuk mengetahui besarnya pengaruh yang diberikan variable bebas terhadap variable terikat dalam hal ini sering disebut dengan koefisien diterminan atau $\mathrm{R}$ squared. Menurut sugiono (2001:129) menyebutkan "bahwa perhitungan koefisien diterminasi berganda digunakan untuk mengukur ketepatan dari model analisis yang dibuat.nilai koefisien diterminasi berganda digunakan untuk mengukur besarnya sumbangan dari variable bebas yang diteliti terhadap variable tergantung. Nilai $R^{2}$ berada antara 0 dan 1 atau $0 \leq$ $R^{2} \leq 1$.Bila nilai $R^{2}$ mendekati nilai 1 maka dapat dikatakan semakin besar, berarti model yang digunakan semakin kuat untuk menerangkan variasi dari variable tergantung.Sedangkan jika $R^{2}$ nilai mendekati 0 maka model yang digunakan semakin lemah dalam menerangkan variasi dari variable tergantung.

\subsubsection{Uji Hipotesis}

Dengan membandingkan $\mathrm{t}$ hitung dan $\mathrm{t}$ table pada $\alpha 0,05$ maka :

a. $\mathrm{t}$ hitung $\leq \mathrm{t}$ table maka Ho diterima dan $\mathrm{Hi}$ ditolak, artinya variable bebas kurang menjelaskan variable terikatnya.

b. t hitung $\geq \mathrm{t}$ table maka $\mathrm{Ho}$ ditolak $\mathrm{Hi}$ diterima, artinya variable bebasnya dapat menjelaskan variable terikatnya.

\section{HASIL PENELITIAN DAN PEMBAHASAN}

\subsection{Hasil Penelitian}

\subsubsection{Seputar Profil (BUMDES)}

BUMDES adalah sebuah badan usaha masyarakat yang siap bersama sama menggali segala potensi yang ada guna meningkatkan roda perekonomian masyarakat pedesaan, agar masyarakat desa menjadi lebih produktif. dan umumnya membantu dalam program peningkatan ekonomi nasional. Ekonomi perdesaan menjadi bagian penting sekaligus masih menjadi titik lemah dalam rangka mendukung penguatan ekonomi perdesaan.

Badan usaha milik desa ialah usaha desa yang di bentuk atau didirikan oleh pemdes (pemerintah desa) yang kepemilikannya dilakukan oleh pemerintah desa dan masyarakat, dalam 
hal ini BUMDES sebagai institusi yang di buat oleh pemerintah desa untuk mengelola /menampung (semua unit-unit usaha milik desa yang berbadan hokum ataupun yang tidak berbadan hokum).Usaha desa adalah jenis usaha yang berupa Kepemimpinan ekonomi desa seperti, usaha jasa, penyaluran Sembilan bahan pokok, perdagangan hasil pertanian, serta industry dan kerajinan rakyat.BUMDES yang berorientasi pada usaha perantara (brokering), usaha bersama (holding), bisnis sosial(sosial business), bisnis keuangan (financial business), dan perdagangan (trading), bisnis penyewaan (renting), mencakup aspek teknis dan tegnologi, aspek keuangan aspek sosial budaya, ekonomi, politik, lingkungan usaha dan lingkungan hidup.

Oleh karenanya diperlukan upaya sistematis untuk mendorong organisasi ini agar mampu mengelola asset ekonomi strategis di desa sekaligus mengembangkan jaringan ekonomi demi meningkatkan daya saing ekonomi perdesaan. Dalam konteks demikian, BUMDES pada dasarnya merupakan bentuk konsolidasi atau penguatan terhadap lembaga-lembaga ekonomi desa.Badan usaha milik desa selanjutnya disebut BUMDES adalah badan usaha yang seluruh atau sebagian besar modalnya dimiliki oleh desa melalui penyertaan secara langsung yang berasal dari kekayaan desa yang di pisahkan guna mengelola asset, jasa Kepemimpinan, dan usaha lainnya untuk sebesar-besarnya kesejahteraan masyarakat desa.

Desa adalah kesatuan masyarakat hokum yang memiliki batas wilayah yang berwenang untuk mengatur dan mengurus urusah pemirintahan, kepentingan masyarakat setempat berdasarkan prakarsa masyarakat, hak asal usul dan hak tradisional yang di akui dan di hormati dalam system pemerintahan negara kesatuan republic
Indonesia.Pemerintah desa adalah kepala desa atau yang di sebut dengan nama lain bantu perangkat desa sebagai unsure penyelenggara pemerintah desa. Badan permusyawaratan desa atau disebut dengan nama lain adalah lembaga yang melaksanakan fungsi pemerintahan yang anggotanya merupakan wakil dari penduduk desa berdasarkan keterwakilan wilayah dan ditetapkan secara demokratis.dan menumbuhkembangkan ekonomi kerakyatan melalui pembinaan usaha mikro guna memacu pertumbuhan usaha dalam rangka peningkatan kesejahteraan masyarakat. Serta memperkuat kelembagaan dan memperluas jaringan kerja melaui kerja sama dengan berbagai potensi masyarakat dan bersinergi dengan lembaga-lembaga keuangan serta lembaga-lembaga pemerintahan. Dan mengembangkan linkage program dengan lembaga-lembaga keuangan sebagai agen dalam memberdayakan usaha mikro.

Bumdesa bersama diatur dengan peraturan menteri yang menyelenggarakan urusan pemerintahan di bidang pembangunan desa, pembangunan perdesaan dan pemberdayaan masyarakat desa berkoordinasi dengan menteri yang menyelenggarakan urusan pemerintahan di bidang pemerintahan dalam negeri.BUMDES adalah sebagai sebuah solusi bagi masyarakat untuk mengakomudasi dari dinamika hidup dalam kalangan produktif yang hanya punya sedikit waktu tapi banyak kegiatan" disamping itu dengan didukung oleh pemerintah desa dan para perangkat desa dengan sopan dan ramah melayani para masyarakat yang berada di desa rombasan. Saat ini bumdesa (BUMDES) memiliki karyawan atau anggota yang siap memberikan Kepemimpinan secara maksimal kepada para masyarakat yang akan mengembangkan usahanya di desa rombasan. 
Oleh sebab itulah dengan di selenggarakannya (BUMDES) setidaknya memiliki persepsi dan pemahaman yang sama tentang badan usaha milik desa. Karena adanya BUMDES menjadi penting dalam konsepsi dinamisasi ekonomi desa. Salah satu peran BUMDES adalah selain memperkuat PADes, juga upaya mendorong peningkatan masyarakat yang dapat di tempuh dengan sejumlah cara, salah satunya adalah dengan cara memberi nilai tambah produk masyarakat, dalam hal produksi dan pengembangan kemampuan SDM sehingga mampu memberikan nilai tambah dalam pengelolaan asset ekonomi desa, mengintegrasi produkproduk ekonomi perdesaan sehingga memiliki posisi nilai tawar baik dalam jaringan pasar,mewujudkan skala ekonomi kompetitif terhadap usaha ekonomi yang dikembangkan,dan mengembangkan unsure pendukung seperti perkreditan mikro, informasi pasar, manajemen, prasarana ekonomi dan jaringan komunikasi maupun dukungan pembinaan dan regulasi.

Pemerinth juga diharapkan dapat menciptakan iklim usaha yang mendorong perkembangan perekonomian secara sehat, baik dalam meningkatkatkan kesejahteran anggota dan juga masyrakat disekitarnya, maupun turut serta dalam membangun system perekonomian nasional sebagai organisasi ekonomi, perkembangan badan usaha milik desa (BUMDES) tidak mungkin dapat dipisahkan dari kondisi persaingan yang dihadapinya dengan pelaku-pelaku ekonomi yang lain.

Menurut data kementrian negara daerah pembangunan daerah tertinggal (KPDT :2009) terdapat 38.232 (54,14 persen) kategori desa maju, yaang terdiri dari 36.793 (52,03 persen) kategori maju dan 1.493 (2,11 persen) kategori amat maju. Sementara itu, desa tertinggal berjumlah 32.379 (45,86 persen) yang terdiri dari $29.634 \quad(41,97$ persen $)$ kategori tertinggal dan $2.745 \quad(3,89$ persen) kategori amat teringgal.

BUMDES yang merupakan pilar kegiatan ekonomi di desa yang berfungsi sebaagai lembaga sosial ( sosial institution) . dan komersial (commercial institution). BUMDES sebagai lembaga sosial yang berpihak kepda masyaraakat melalui kontribusinya dalam penyediaan Kepemimpinan sosial. Sedangkan sebagai lembaagaa komercial bertujuan mencari keuntungan melalui penawaaran sumber daya lokal (barang dan jasa ) dalam menjalankan usahanya prinsip efisiensi dan efektifitas harus selalu ditekankan. BUMDES sebagia badan hukum, di bentuk berdasarkan tata perundang-undangan yang berlaku, dan sesuai dengan kesepakatan yang terbangun di masyarakat desa. Dengan demikian, Bentuk bumdes dapat beragam di setiap desa di indonesia. Ragam benruk ini sesuai dengan karakteristik lokal, potensi, dan sumber daya yang dimiliki masing-masing desa.Peraturan lebih lanjut tentang BUMDES di atur melalui peraturan Daerah (Perda).

Pemerintah adalah melaakukan sosialisasi dan penyadaran kepada masyarakat desa melalui pemerintah profinsi atau pemerintah kabupaten tentang arti penting BUMDES bagi peningkatan kesejahteraan Masyarakat.Melaui pemerintah desa masyarakat dimotivasi, disadarkan dan dipersiapkan untuk membangun kehidupannya sendiri.Pemerintah memfasilitasi dalam bentuk pendidikan dan pelatihan dan pemenuhan lainnya yang dapat memperlancar BUMDES.Selanjutnya, mekanisme operasionalisasi diserahkan sepenuhnya kepada masyarakat desa.Untuk itu, masyarakat desa perlu dipersiapkan terlebih dahulu agar dapat menerima gagasan baru tentang lembaga ekonomi.Dengan tetap berpegang teguh 
pada karakteristik desa dan nilai-nilai yang hidup daan dihormati.Pelatihan kepada pihak-pihaak yang berkepentingan terhadap peningkatan standar hidup masyarkat desa (pemerintah Desa, BPD, tokoh masyarakat /ketua-ketua kelembagaan dipedesaan).

\subsubsection{Data Hasil Penelitian}

Dari hasil angket yang dikumpulkan dalam penelitian yang dilakukan terhadap masyarakat asli Desa Rombasan sumenep yang sedang mengembangkan usahanya (BUMDES) maka diperoleh gambaran tentang karakteristik responden pada tingkatan usia, jenis kelamin, adalah sebagai berikut:

a. Karakteristik Berdasarkan Usia

Dari hasil jawaban Responden dapat dijelaskan bahwa dapat di tinjau dari kelompok umur <20th sebanyak 14 responden, 20th - 29th sebanyak 22 Responden, 30th - 35th sebanyak 43 responden yang berumur 36th- 40th sebanyak 35 Responden dan yang berumur 41th - 45 th sebanyak 11 responden

b. Karakteristik

Responden

Berdasarkan jenis Kelamin

Dari hasil jawaban responden dapat dijelaskan bahwa sebagian besar yang menjadi responden adalah perempuan dengan jumlah responden 80 dan Laki-Laki dengan jumlah 45 Responden.

\subsubsection{Uji Validitas dan UJi Reliabilitas}

\section{a. Uji Validitas}

Uji Validitas data bertujuan untuk mengetahui sejauh mana Validitas data yang diperoleh dari penyebaran Kuesioner. Uji Validitas data menggunakan metode korelasi product moment (pearson correlation), (Sugiono 2002:277).

Berdasarkan hasil perhitungan Korelasi dari Variable semua Factor maka untuk mengetahui Validitas dari semua Variabel maka dilakukan uji Validitas semua Faktor yang akan di Teliti. Variabel dinyatakan Valid apabila Koefisien Korelasi r>0,3.

Berdasarkan table, dari hasil uji
validitas ternyata semua Indicator Variable Valid karena Koefisien Korelasinya $>0,3$ atau Valid sehingga indicator variabel dapat diikutkan dalam proses selanjutnya.

\section{b.Uji Reliabilitas}

Menurut (Danim 2000:199) Menyatakan bahwa pengujian keandalan alat ukur dalam penelitian ini menggunakan Metode Cronbach Alpha.Tujuan dari uji Reliabilitas adalah untuk mengetahui tingkat kehandalan dari instrument penelitian. Variabel dapat dinyatakan handal apabila Koefisien Alpha > 0,5 dengan menggunakan Metode Alpha Cronbach dengan menggunakan bantuan SPSS Program Versi 16.00 .

\subsection{Pembahasan}

\subsubsection{Analisa Kualitatif}

Berdasarkan data hasil angket yang telah dikumpulkan maka dapat dijelaskan distribusi jawaban responden dari:

a. Variable Kepemimpinan (X) dengan indicator sebagai berikut:

\section{Akurasi Kepemimpinan}

Berdarsarkan

tanggapan

Respondent yang menjawab cukup setuju sebanyak 27 orang atau 21,6\% Responden yang menjawab setuju sebanyak 28 orang atau $22,4 \%$ dan yang menjawab sangat setuju sebanyak 70 orang atau $56 \%$ dari tanggapan 
respondent tentang akurasi Kepemimpinan diberikan sebagian besar Respondent menyatakan sangat setuju. Hal ini menunjukan bahwa masyarakat mendapatkan suatu Kepemimpinan benar-benar dirasakan akan Kepemimpinan oleh BUMDES sesuai dengan sasaran dan tujuan.

\section{Kesopanan / keramahan}

Berdasarkan table tanggapaan Respondent, Responden yang menjawab Cukup setuju sebanyak 37 orang atau $29,6 \%$ Responden yang menjawab Setuju sebanyak 57 orang atau 45,6\% dan yang menjawab Sangat setuju sebanyak 31 orang atau $24,8 \%$

\section{Tanggung Jawab}

Berdasarkan table Responden yang menjawab Cukup setuju sebanyak 25 orang atau $20,0 \%$, Responden yang menjawab setuju 31 orang atau $24.8 \%$, dan yang menjawab sangat setuju sebanyak 69 orang atau $55.2 \%$

\section{Kelengkapan}

Berdasarkan table Responden yang menjawab Cukup setuju sebanyak 43orang atau $34.4 \%$ Responden yang menjawab Setuju sebanyak 37 orang atau $29.6 \%$ dan yang menjawab Sangat setuju sebanyak 45 orang atau $36 \%$ dapat di simpulkan bahwa sebagian besar Responden menyatakan setuju bahwa BUMDES menyediakan sarana kelengkapan penunjang Kepemimpinan diantaranya tersedianya tempat parker yang memadai adanya pendingin ruangan atau $A C$, pengaturan lay out yang menarik dan penataan ruangan dan tempat barang yang baik.

\section{Kemudahan}

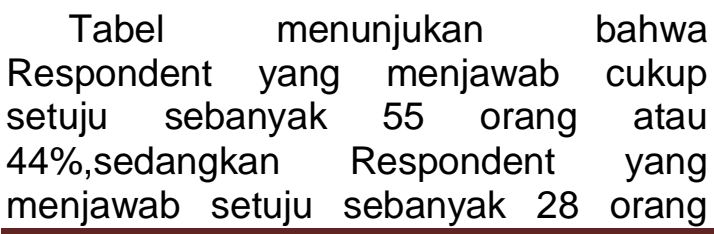

atau 22,4\% dan Respondent yang menjawab sangat setuju sebanyak 42 orang atau $33,6 \%$ dapat disimpulkan bahwa sebagian besar Respondent menyatakan cukup setuju bahwa BUMDES memberikan kemudahan Kepemimpinan yang secara maksimal kepada para masyarakat.

\section{Kenyamanan}

Berdasarkan tabel menunjukan Respondent yang menjawab tidak setuju sebanyak 1 orang atau $8 \%$, Respondent yang menjawab cukup setuju sebanyak 33 orang atau $26,4 \%$, Respondent yang menjawab setuju sebanyak 61 orang atau $48,8 \%$ dan Respondent yang menjawab sangat setuju sebanyak 30 orang atau $24 \%$ dapat disimpulkan sebagian besar responden menyatakan setuju bahwa Kepemimpinan kepada setiap masyarakat yang mengembangkan usahanya BUMDES mudah dan nyaman. BUMDES menciptakan sistem Kepemimpinan yang memberikan kenyamanan kepada masyarakat sehingga masyarakat yang sedang mengembangkan usaha merasa enak dan nyaman. Setiap masyarakat yang mau bergabung dengan BUMDES dalam upaya untuk mendapatkan Kepemimpinan berupa informasi baru tentang usaha atau bisnis yang bisa dikembangkan di desa sehingga masyarakat harus dimanjakan dan diberikan kemudahan Kepemimpinan sehingga para masyarakat yang ingin mengembangkaan usahanya tidak merasa kesulitan serta para masyarakat bisa mendapatkan suatu informasi yang sangat inovatif dalam mengembangkan usahanya dan dapat meningkat keuntungan yang lebih dari usaha yang sedang dikembangkan. Untuk itu seluruh pengurus BUMDES beserta ketua harus bertanggung jawab dalam memberikan Kepemimpinan dan informasi kepada para masyarakat yang datang sebagai suatu wujud dari Kepemimpinan yang diberikan.Sehingga para masyarakat 
merasa puas terhadap segala jasa dan informasi penting yang dapat diterima oleh para masyarakat.

\section{b. Variable kinerja masyarakat dengan indicator sebagai berikut:}

\section{Mengembangkan usahanya dengan baik}

Tabel menunjukan bahwa Responden yang menjawab Cukup setuju sebanyak 31 orang atau $24,8 \%$ Responden yang menjawab Setuju sebanyak 26 orang atau $20,8 \%$ dan yang menjawab Sangat setuju sebanyak 68 orang atau 54,4\%. Dapta disimpulkan bahwa sebagian besar Responden menyatakan Sangat setuju bahwa para masyarakat yang bergabung dengan BUMDES akan mengembangkan usahanya dengan baik karena mendapatkan layanan sesuai dengan layanan yang di harapkan.

\section{Bersedia merawat dan mengembangkan potensi desa}

Table menunjukan bahwa Responden yang menjawab Tidak setuju sebanyak 6 orang atau $4,8 \%$ Responden yang menjawab Cukup setuju sebanyak 37 orang atau $29,6 \%$ Responden yang menjawab Setuju sebanyak 42 orang atau 33,6\% dan yang menjawab Sangat setuju sebanyak 40 orang atau $32,0 \%$.

\section{Berbagi Informasi Kepada Orang Lain}

Table di atas menunjukan bahwa Responden yang menjawab Cukup setuju sebanyak 31 orang atau $24,8 \%$ Responden yang menjawab Setuju sebanyak 31 orang atau $24,8 \%$ dan Responden yang menjawab Sangat setuju sebanyak 63 orang atau 50,4\%.

\section{Meningkatkan Ekonomi Melalui Potensi Desa}

Berdasarkan table menunjukan bahwa Responden yang menjawab Cukup setuju sebanyak 35 orang atau $28 \%$ Responden yang menjawab Setuju sebyak 27 orang atau $21,6 \%$ dan Responden yang menjawab Sangat setuju sebanyak 63 orang atau $50,4 \%$.

\section{Menekuni Usahanya dengan Baik}

Berdasarkan table menunjukan bahwa Responden yang menjawab Cukup setuju sebanyak 33 orang atau $26,4 \%$ Responden yang menjawab Setuju sebanyak 34 orang atau $27,2 \%$ dan Responden yang menjawab Sangat setuju sebanyak 58 orang atau $46,4 \%$ Dapat di simpulkan bahwa sebagian besar Responden menyatakan Sangat setuju.

\section{Loyalitas}

Berdasarkan table menunjukan bahwa Responden yang menjawab cukup setuju sebanyak 28 orang atau $22,4 \%$ Responden yang menjawab Setuju sebanyak 34 orang atau $27,2 \%$ dan yang menjawab Sangat setuju sebanyak 63 orang atau 50,4\%. Dapat disimpulkan bahwa sebagian besar Responden menyatakan Sangat setuju.

\subsubsection{Analisa Kuantitatif}

Untuk mengetahui hubungan dan pengaruh antara variable bebas dengan variable terikat yaitu dengan menggunakan perhitungan statistic dengan menggunakan regresi linear berganda. Dengan menggunakan bantuan program SPSS for windows versi 16.00 dapat diketahui sebagai berikut:

\section{a. Hasil Perhitungan Korelasi}

Dari hasil perhitungan korelasi seperti table korelasi, menunjukan hubungan antara variable bebas dengan variable terikat dapat dijelaskan bahwa korelasi Kepemimpinan terhadap 
produktifitas masyarakat sebesar 0,853 atau $85,3 \%$, hal ini menunjukan bahwa Kepemimpinan mempunyai pengaruh kuat terhadap Produktifitas Masyarakat dalam mengembangkan usaha (BUMdes) di Desa Rombasan Sumenep

\section{b. Hasil Perhitungan $\mathbf{R}$ dan $\mathbf{R}$ Square}

Hasil perhitungan $\mathrm{R}$ dan $\mathrm{R}$ Square memberikan informasi tentang hubungan atau korelasi antara Variabel bebas Kepemimpinan dengan Variabel terikat yaitu produktifitas masyarakat. Nilai $R$ atau multiple R Sebesar 0,853 atau 85,3\% yaitu menggambarkan hubungan antara variable bebas bersifat searah dan kuat. Sedangkan nilai $R$ Squared atau diterminan $\mathrm{R}$ sebesar 0,727 atau $\quad 72,7 \%$ artinya $28,3 \%$ dipengaruhi oleh factor lain yang tidak di teliti pada penelitian ini.

\section{c.Koefisien}

Berdasarkan table coefficients, dapat di susun persamaan regresi linear berganda sebagai berikut:

$$
Y=1,676+0,571 X
$$

Nilai konstanta sebesar 676 1, hal ini berarti bahwa pada saat $X$ sama dengan NOL maka produktifitas masyarakat dalam mengembangkan usahanya yang di desa rombasan sumenep sebesar 1,676.

\subsubsection{Uji Hipotesis}

\section{a. Uji t}

Uji $t$ atau $t$ tes adalah bertujuan untuk menguji signifikansi variable dependen terhadap variable independent.Untuk membuktikan kebenaran dari Hipotesis yang ada dalam penelitian ini maka perlu dibuktikan dengan melakukan uji Hipotesa yaitu dengan menggunakan uji $\mathrm{t}$ atau $\mathrm{t}$ tes. Uji Hipotesis atau Uji $\mathrm{t}$ berdasarkan hasil perhitungan diperoleh t hitung untuk Variabel Kepemimpinan (X) yang terdiri dari Akurasi Kepemimpinan,

Kesopanan,Kepemimpinan, Tanggung Jawab Kepemimpinan, Kelengkapan Kepemimpinan, Kemudahan Kepemimpinan, dan Kenyamanan Kepemimpinan sebesar 7,014 dan kalau dikonsultasikan dengan $t$ table sebesar 1,645 di dapat $t$ hitung $>t$ table maka dapat diambil kesimpulan bahwa dugaan bahwa Variabel Kepemimpinan berpengaruh terhadap Produktifitas Masyarakat dalam mengembangkan usahanya di Desa Rombasan dibuktikan kebenarannya, hal ini dapat dilihat dari nilai t hitung lebih besar dari table.

\section{KESIMPULAN DAN SARAN}

\subsection{Kesimpulan}

Berdasarkan hasil penelitian dan pembahasan maka peneliti dapat membuat kesimpulan sebagai berikut:

a. Dari hasil analisis statistic ternyata Kepemimpinan berpengaruh terhadap Produktifitas Masyarakat dalam mengembangkan usaha di Desa Rombasan Sumenep adapun pengaruh yang diberikan oleh Variabel tersebut sebesar 0,853 atau $85,3 \%$

b. Nilai Uji $t$ atau $t$ hitung untuk Kepemimpinan sebesar 7,014 dengan probabilitas 0,00 dengan probabilitas 0,00 sedangkan nilai $t$ tabel sebesar 1,645 dan taraf nyata sebesar 0,05 maka dapat diambil suatu kesimpulan dugaan bahwa Kepemimpinan berpengaruh terhadap Produktifitas Masyarakat dalam mengembangkan usahanya di Desa Rombasan dapat dibuktikan kebenarannya.

5.2 Saran - saran

a. Hendaknya Badan Usaha Milik Desa (BUMdes) selalu meningkatkan Kepemimpinan kepada para Masyarakat sehingga dapat 
memberikan kepuasan dengan rasa puas maka produktifitas masyarakat dapat meningkat.

b. Hendaknya pihak badan usaha milik Desa (BUMdes) untuk lebih proaktif dalam memberikan informasi tentang usaha/bisnis

beserta Kepemimpinannya yang ditawarkan kepada masyarakat.

\section{DAFTAR PUSTAKA}

Buchari, Alma Prof. DR. H. 2005. Manajemen pemasaran, edisi revisi CV. Alfa beta Bandung

Armanu Thoyib, 2005, " Hubungan Kepemimpinan Budaya, strategi, dan Kinerja: pendekatan konsep ,: Jurnal Manajemen \& Kewirausahaan, vol. 7, No. 1 , maret 2005 , h. $60-73$

Cokroaminoto, 2007, " membangun kinerja (memakai kinerja karyawan)," google /15012008/ Cokroaminoto.wordpres.com/20070523/ Memaknai Kinerja Karyawan.

Cooper, R Donald \& c. William Emory, 2006, "Metode Penelitian Bisnis", penerbit Erlangga jilid 1, edisi kelima. Dwicahyono dan Imam Ghazali, 2002, "Pengaruh Jabatan Budaya Organisasional, dan Konflik peran terhadap Hubungan Kepuasan Kerja, dengan Komitmen Organisasi: Studi Empiris di kantor Akuntan Public," jurnal Risert Akuntasi Indonesia vol. 5 No. 3, September 2002, h. 341-364

Flippo, Edwin B, 1994,"Manajemen Personalia", Edisi keenam, jilid2, Penerbit Erlangga Jakarta.
Fu'ad mas'ud 2004, " survai diagnosis organisasional," badan penerbit universitas diponegoro semarang.

H. hadari Nawawi, 2003 "Kepemimpinan Mengefektifkan Organisasi," Gajah Mada Universitas Press, Yogyakarta.

$\mathrm{H}$. hadari nawawi 2005 "Manajemen Sumber Daya Manusia ( Untuk Bisnis yang kompetitif)" Gajah Mada Universitas press, Yogyakarta.

Keputusan Menteri Pendaya Gunaan Aparatur RI nomor 25/KEP/M.PAN/04/2002 tentang pedoman Pengembangan Budaya Kerja Aparatur Negara.

Kreitner, Robert, dan knicki, Angelo, 2005 "Prilaku Organisasi" buku 1, EdisiKelima, salemba Empat Jakarta.

Kreitner, Robert dan knicki "Prilaku Organisasi" Buku 2, Edisi Kelima, Salemba Empat, Jakarta.

Luthans, fred, 2006, "Prilaku Organisasi" edisi sepuluh penerbit, andi Yogyakarta.

Mahmudi, 2005.“ Manajemen Kinerja Sektor Public”, Akademi Manajemen perudasaan YKPN

Mathis Robert $L$ dan Jackson, john $H$, 2001, "Manajemen Sumber Daya Manusia" Buku 1, Salemba Empat Jakarta.

Miftah Toha 1983, "Prilaku Organisasi" Konsep Dasar Dan Aplikasinya, Edisi 1 PT. Raja Grafindo Persada Jakarta.

Melayu S.P Hasibuan. 1996. Organisasi dan Motivasi, Dasar Peningkatan Produktifitas, Jakarta : Bumi Aksara Putra. 